\title{
PENATALAKSANAAN PLEOMORFIK ADENOMA PALATUM
}

\author{
Sukri Rahman, Bestari Jaka Budiman, Yolazenia
}

\begin{abstract}
Abstrak
Pleomorfik adenoma merupakan tumor jinak campuran yang terdiri dari komponen sel epitel, mioepitel dan mesenkim yang tersusun dalam beberapa variasi. Tumor ini paling sering ditemukan pada kelenjar liur. Kelenjar liur mayor yang paling umum dikenai adalah kelenjar parotis, sedangkan kelenjar liur minor paling sering terjadi pada palatum. Terapi pilihan untuk pleomorfik adenoma kelenjar liur adalah reseksi tumor. Kasus ini diajukan agar dokter umum dan dokter spesialis Telinga, Hidung, Tenggorok dapat mengetahui diagnosis dan penatalaksanaan pasien dengan pleomorfik adenoma pada palatum. Dilaporkan satu kasus pada seorang pasien laki-laki umur 49 tahun dengan benjolan yang tidak nyeri di palatum sejak 3 bulan sebelum masuk rumah sakit, histopatologi mengkonfirmasi pleomorfik adenoma sebagai diagnosisnya. Pada pasien ini dilakukan reseksi tumor sebagai penatalaksanaannya. Tumor jinak pada palatum sering berupa pleomorfik adenoma yang bila dilakukan reseksi tumor secara komplit memberikan prognosis yang baik.
\end{abstract}

Kata kunci: pleomorfik adenoma, kelenjar liur, palatum, reseksi tumor

\begin{abstract}
Pleomorphic adenoma is a benign mixed tumour composed of epithelial, myoepithelial, and mesenchymal components arranged with various morphological patterns. This is the most common tumour of the salivary glands. The parotid gland was the most commonly affected major gland, and the palate the most common site of minor salivary gland involvement. Treatment of choice for pleomorphic adenoma of salivary gland is tumour resection. This case is presented to enlighten general practitioners and also otorhino-laryngologists about diagnosis and treatment of pleomorphic adenoma of the palate. Reported case of a 49 years old male with painless mass on the palate since 3 months before admission. Pathologic examination confirmed the diagnosis was pleomorphic adenoma. Tumour resection was performed to manage the patient. Pleomorphic adenoma is the most common benign tumour of the palate, which has good prognosis with complete resection of the tumour.
\end{abstract}

Keywords: pleomorphic adenoma, salivary glands, palate, tumour resection

Affiliasi penulis : Bagian THTL-KL Fakultas Kedokteran Universitas Andalas,Korespondensi : Yolazenia,Bagian THTL-KL Fakultas Kedokteran Universitas Andalas,Jl.Perintis Kemerdekaan No.94 PO BOX 49 Padang 25127, email : yolazenia@gmail.com, Telp\HP: 08136365989440 


\section{PENDAHULUAN}

Pleomorfik adenoma merupakan tumor jinak campuran yang terdiri dari komponen sel epitel, mioepitel dan mesenkim yang tersusun dalam beberapa variasi komponen., ${ }^{1,2}$ Tumor ini paling sering ditemukan pada kelenjar liur mayor dan minor. Kelenjar liur mayor terdiri dari: parotis, sub-mandibula dan sublingual. Kelenjar liur minor terdapat di sepanjang saluran aerodigestif bagian atas termasuk: palatum, bibir, faring, nasofaring, laring dan ruang parafaring. ${ }^{1}$ Pleomorfik adenoma pada kelenjar liur mayor paling umum ditemukan pada kelenjar parotis, ${ }^{1,3,4}$ sedangkan pada kelenjar liur minor sering dijumpai pada pa-latum, diikuti dengan bibir atas dan mukosa bukal. ${ }^{5-10}$

Pleomorfik adenoma dapat terjadi pada semua umur, tetapi lebih sering ditemukan pada wanita dibanding lakilaki dengan perbandingan sekitar 2:1.68,11-14 Insiden tertinggi terjadi pada umur 30-60 tahun. ${ }^{12}$

Gambaran klinis pleomorfik adenoma berupa: massa tumor tunggal, keras, batas tegas, mobile, pertumbuhan lambat, tanpa rasa sakit. ${ }^{9,13}$ Tumor ini tergolong jinak, tetapi dapat membesar dan berubah menjadi ganas membentuk karsinoma. ${ }^{3,8,15}$

Gambaran histopatologi dari pleomorfik adenoma bervariasi. Tumor ini terdiri dari 3 komponen: sel epitel, sel mioepitel, dan stroma (mesenkim). Diagnosis histopatologi pleomorfik adenoma dapat dilakukan dengan Biopsi Aspirasi Jarum Halus (BAJAH) dan biopsi insisi.2,16,17 Pemeriksaan Computed Tomography Scan (CT) dilakukan untuk mengetahui lokasi, besar dan batas tumor. ${ }^{12}$
Penatalaksanaan pilihan untuk pleomorfik adenoma adalah reseksi tumor. Reseksi pleomorfik adenoma pada kelenjar liur minor memerlukan eksisi luas tumor. $9,10,13,14,16$

\section{LAPORAN KASUS}

Seorang laki-laki usia 49 tahun datang ke poliklinik THT-KL RS. M. Djamil Padang pada tanggal 22 Juli 2013 dengan keluhan utama benjolan pada langit-langit mulut sejak 3 bulan yang lalu. Benjolan baru diketahui 3 bulan yang lalu sewaktu bercermin, dirasakan tidak membesar sampai sekarang. Suara sengau sejak 1 bulan yang lalu. Sukar menelan tidak ada, pasien masih bisa makan seperti biasa. Keluar darah dari mulut tidak ada, hidung tersumbat tidak ada, hidung berdarah tidak ada, bengkak pada leher tidak ada dan penurunan berat badan tidak ada. Riwayat merokok sejak 35 tahun yang lalu, satu bungkus/hari. Pasien bekerja sebagai kuli bangunan.

Hasil pemeriksaan fisik menunjukkan status generalis keadaan umum sedang, kesadaran komposmentis kooperatif, tekanan darah 120/80 $\mathrm{mmHg}$, nadi $88 \mathrm{x} /$ menit, frekuensi nafas 20 $\mathrm{x} /$ menit dan suhu $36,5^{\circ} \mathrm{C}$. Pada pemeriksaan telinga, hidung dan tenggorok tidak ditemukan kelainan. Pemeriksaan rongga mulut memperlihatkan massa di palatum durum sampai palatum mole ukuran $5 \times 4 \times 2 \mathrm{~cm}$, warna merah muda, permukaan rata, ada bagian yang berbenjol-benjol, tidak mudah berdarah, tidak nyeri tekan (gambar 1). Pada leher tidak terdapat pembesaran kelenjar getah bening. 


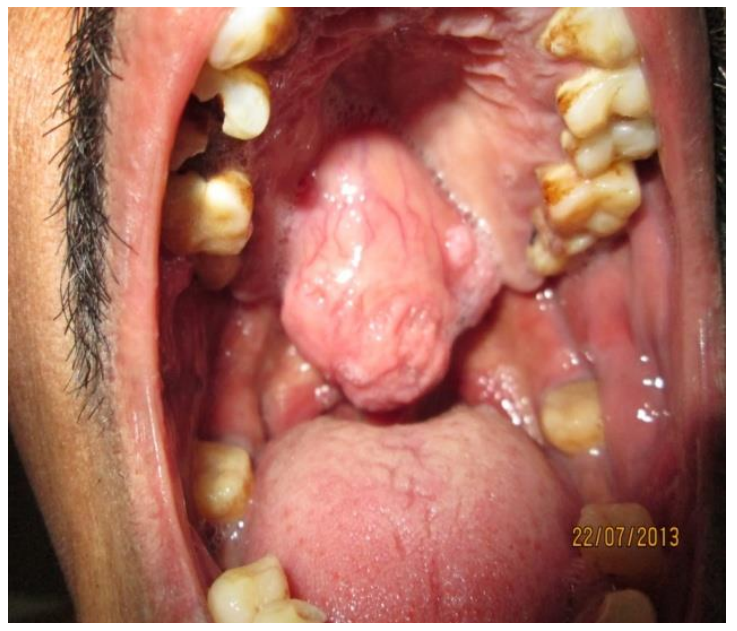

Gambar 1. Tumor pada palatum

Pada tanggal 2 Agustus 2013 dilakukan biopsi tumor dalam anestesi lokal. Gambaran histopatologi dari biopsi tumor ditemukan jaringan terdiri atas stroma jaringan ikat dengan bagian miksokhondroid disertai adanya sel-sel epitel kubis yang tersusun tubular, lumen berisi masa eosinofilik, adanya kelompokan epitel yang berdifferensiasi skuamosa, sel mioepitel serta sel lemak, tak tampak kapsul dalam jaringan ini, tak tampak tanda ganas. Gambaran mikroskopik sesuai untuk suatu pleomorfik adenoma (gambar 2).

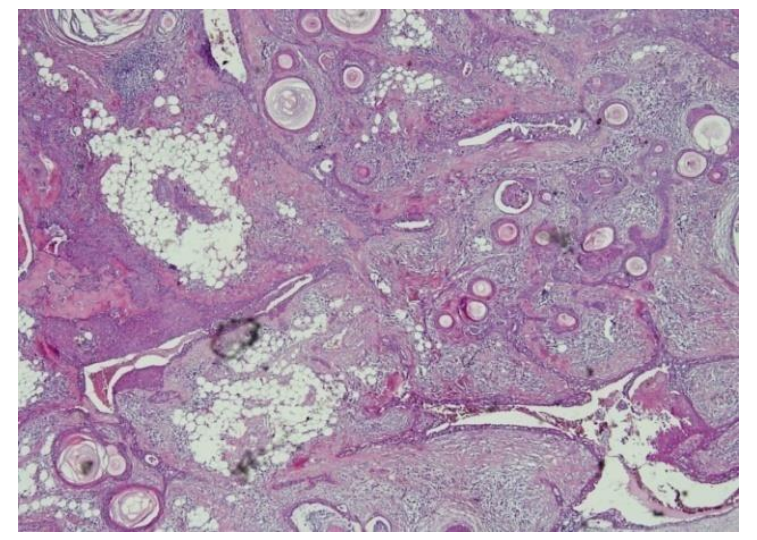

Gambar 2. Histopatologi
Pemeriksaan CT Scan Orofaring tanggal 23 Juli 2013 didapatkan gambaran soft tissue mass, batas tegas, tepi sedikit irregular, tulang-tulang sekitar intak. Kesan: tumor regio posterior palatum (gambar 3).

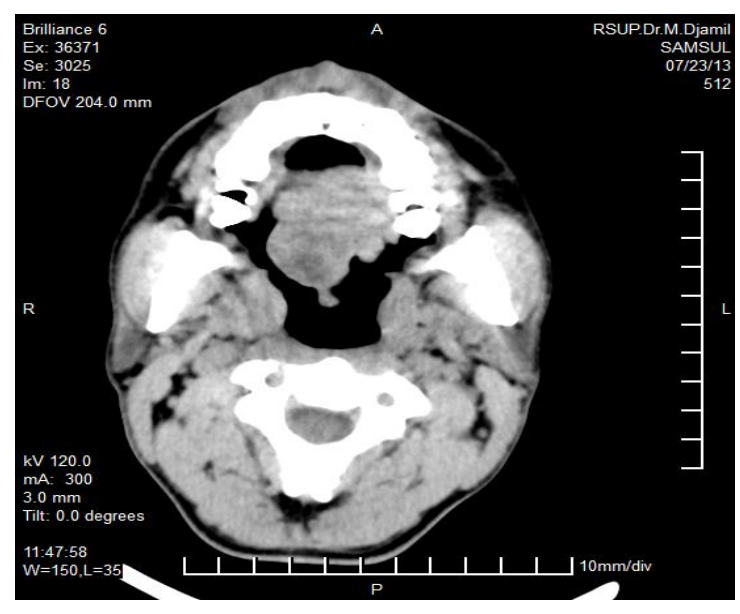

Atas

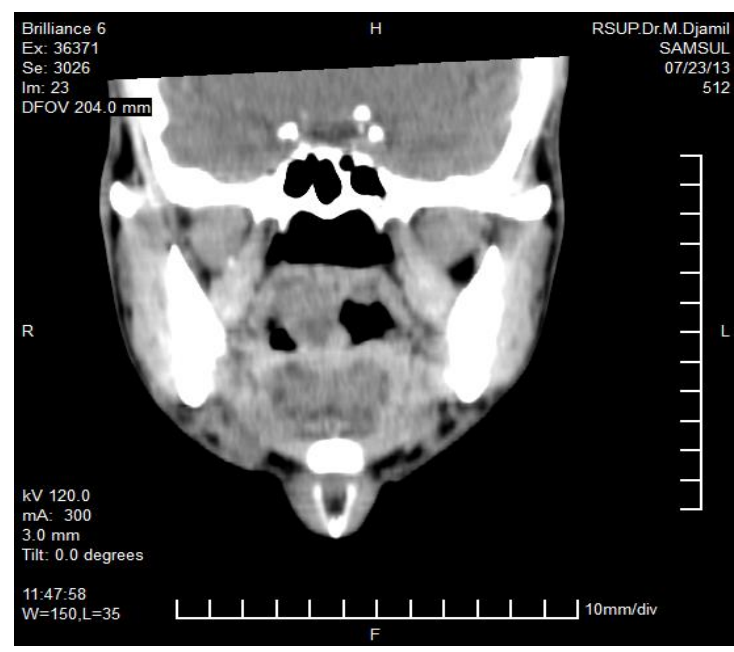

Bawah

Gambar 3. CT Scan Potongan Aksial (atas) dan Koronal (ba-wah)

Pasien didiagnosis dengan pleomorfik adenoma palatum dan direncanakan untuk ekstirpasi tumor dalam anestesi umum. Pemeriksaan laboratorium lengkap, Elektrokardiografi, Rontgen foto thoraks dan konsul penyakit dalam untuk toleransi operasi. 
Pada pemeriksaan laboratorium didapatkan kadar hemoglobin 15,2 g/dl, leukosit $13.000 / \mathrm{mm}^{3}$, hematokrit $47 \%$, jumlah trombosit $307.000 / \mathrm{mm}^{3}$, Prothrombin Time (PT) 11,3 detik, Activated Partial Thromboplastin Time (APTT) 42 detik, glukosa darah puasa $125,7 \mathrm{mg} / \mathrm{dl}$, glukosa darah 2 jam post-prandial 136 $\mathrm{mg} / \mathrm{dl}, \mathrm{Na} 138 \mathrm{mmol} / \mathrm{L}, \mathrm{K}$ 4,2 mmol/L, Cl $103 \mathrm{mmol} / \mathrm{L}$, SGOT $16 \mathrm{U} / \mathrm{L}$, SGPT 10 $\mathrm{U} / \mathrm{L}$, ureum $23,3 \mathrm{mg} / \mathrm{dl}$, dan kreatinin 0,8 $\mathrm{mg} / \mathrm{dl}$.

Pada tanggal 3 September 2013 dilakukan ekstirpasi tumor dalam anestesi umum. Operasi dimulai dengan pasien tidur di meja operasi posisi supine. Dilakukan tindakan asepsis dan antisepsis di lapangan operasi. Dipasang davis gag. Dilakukan infiltrasi dengan adrenalin $1: 200.000$ di sekitar massa tumor. Insisi dilakukan di sekitar tumor dengan elektrokauter, kemudian dibebaskan secara tumpul. Tumor dapat diangkat secara utuh dengan ukuran $5 \mathrm{x}$ $4 \times 2 \mathrm{~cm}$, terdapat defek pada palatum durum dengan ukuran $2 \times 1,5 \times 0,5 \mathrm{~cm}$ (gambar 4). Perdarahan pada defek dirawat, kemudian dipasang Naso Gastric Tube (NGT).

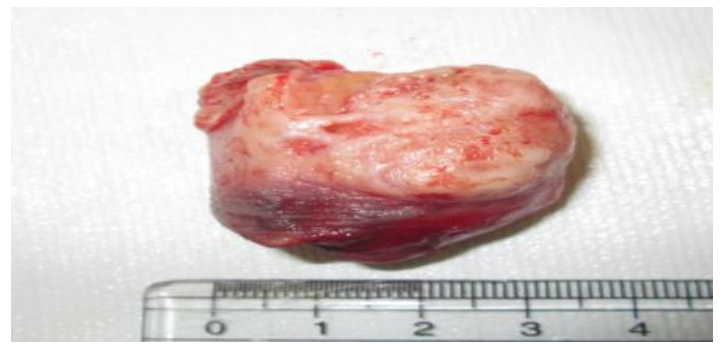

Gambar 4. Massa Tumor

Pasca operasi, pasien dirawat dan diberi terapi injeksi seftriakson $2 \times 1$ gram (iv), dan asam mefenamat $3 \times 500$ mg (po). Pada hari ketiga setelah operasi (tanggal 7 September 2013) keluhan pasien tidak ada. Gambar 5 memperlihatkan pada rongga mulut tampak defek di palatum durum ukuran 2 $x 1,5 \times 0,5 \mathrm{~cm}$, dan terdapat fibrin. NGT pasien dilepas, pasien diperbo-lehkan pulang dan dianjurkan untuk diet makanan lunak.

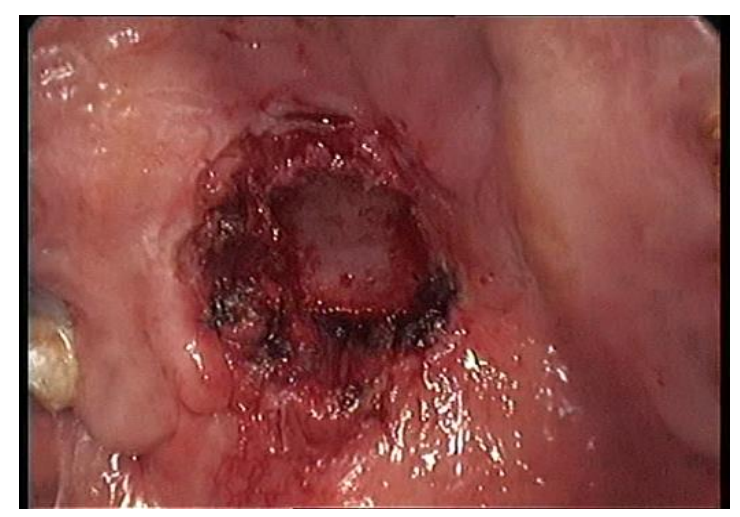

Gambar 5. Defek Palatum Pasca Operasi

Pada saat kontrol 2 minggu pasca operasi tanggal 16 September 2013, pemeriksaan pada palatum tampak adanya fibrin pada defek, tidak ada tanda infeksi. Histopatologi dari massa tumor yang diekstirpasi adalah pleomorfik adenoma dengan diferensiasi skuamosa.

Pemeriksaan rongga mulut setelah 1,5 bulan pada palatum tampak defek sudah menutup (gambar 6).

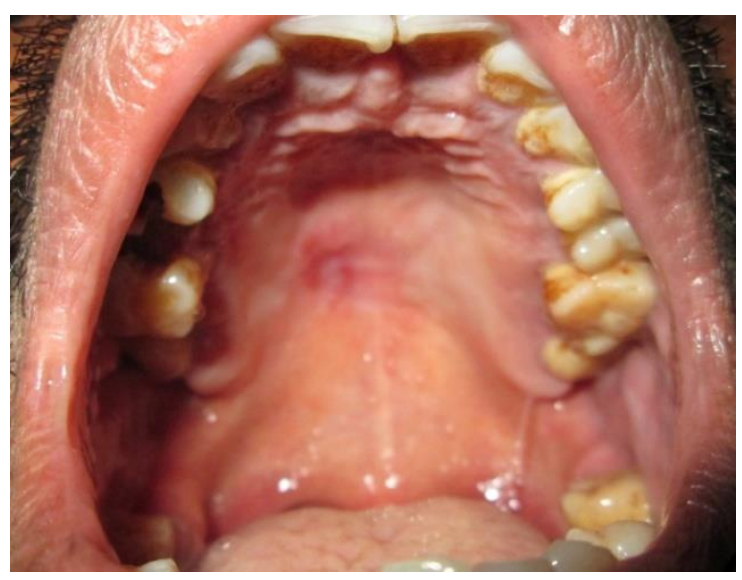

Gambar 6. Defek Pada Palatum 1,5 Bulan Setelah Operasi 


\section{PEMBAHASAN}

Tumor kelenjar liur terjadi kurang dari $3 \%$ dari tumor kepala dan leher. ${ }^{2,18-}$ 20 Tumor pada kelejar liur minor terjadi sekitar $22 \%$ dari semua tumor kelenjar liur. 8,13 Pleomorfik adenoma adalah tumor jinak yang paling banyak ditemukan pada kelenjar liur, sedangkan tumor ganas terbanyak adalah adenoid kistik karsinoma. ${ }^{5-7}$ Pleomorfik adenoma terutama terjadi pada kelenjar parotis, ${ }^{1,3,4}$ sedangkan pada kelenjar liur minor sering dijumpai pada palatum diikuti dengan bibir atas dan mukosa bukal. ${ }^{5-10,20}$

Pleomorfik adenoma dapat terjadi pada semua umur, lebih sering ditemukan pada wanita dibanding lakilaki dengan perbandingan mencapai 2:1. 6-12 Tumor ini sering ditemukan pada dewasa dan jarang pada anakanak. ${ }^{8,11,21}$ Insiden tertinggi terjadi pada umur 30-60 tahun. ${ }^{12}$ Pada kasus ini pasien adalah seorang laki-laki berumur 49 tahun.

Gejala klinik pleomorfik adenoma berupa massa yang tumbuh lambat dan tidak nyeri, tanpa adanya ulserasi atau inflamasi.9,14 Tanda ini sesuai dengan pasien yang baru menyadari adanya tumor pada langit-langit mulut sejak 3 bulan yang lalu sewaktu ber-cermin tanpa adanya gejala lain yang mengganggu.

Diagnosis pasti dapat ditegakkan dengan melakukan biopsi aspirasi jarum halus atau biopsi insisi pada tumor. Gambaran histopatologi dari pleomorfik adenoma bervariasi. Tumor terdiri dari 3 komponen: sel epitel, sel mioepitel dan stroma. 2,16,17 Histopatologi menunjukkan gambaran pulau-pulau sel stellata dan spindle yang tersebar dengan latar belakang miksoid. ${ }^{2}$ Beberapa varian pleomorfik adenoma dapat ditemukan seperti: perubahan lipomatosa, miksolipomatosa dan diferensiasi skuamosa. ${ }^{18}$ Pemeriksaan histopatologi tumor pada pasien setelah ekstirpasi didapatkan gambaran pleomorfik adenoma dengan diferensiasi skuamosa.

Pemeriksaan CT Scan penting untuk membantu menentukan perluasan tumor dan keterlibatan tulang. ${ }^{19}$ Pemeriksaan penunjang lain untuk tumor kelenjar liur adalah ultrasound dan Magnetic Resonance Imaging (MRI)..$^{9} \mathrm{CT}$ lebih unggul dari MRI dalam mengevaluasi tulang, terutama untuk diagnosis erosi dan perforasi tulang palatum dan kemungkinan keterlibatan kavum nasi atau sinus maksila. MRI dengan resolusi tinggi untuk jaringan lunak, memberikan gambaran yang lebih baik pada perluasan tumor secara vertikal dan inferior. ${ }^{11,21}$ Pada pasien ini dilakukan pemeriksaan CT Scan dan ditemukan gambaran soft tissue mass, batas tegas, tepi sedikit irregular, tulangtulang sekitar intak.

Reseksi bedah adalah terapi pilihan pada pasien. Terapi pilihan dari pleomorfik adenoma pada kelenjar liur minor adalah eksisi luas dengan margin negatif dengan pengangkatan periosteum atau tulang jika terlibat. ${ }^{9-11,14,15,17}$ Defek post operasi dapat direkonstruksi dengan obturator prostetik, flap lokal, dan flap free radial forearms. ${ }^{6}$ Mubeen melaporkan kasus pleomorfik adenoma yang ditatalak-sana dengan eksisi luas diikuti pemasangan obturator dan tidak ditemukan rekuren dalam satu tahun pemantauan. Penyembuhan komplit dari defek membutuhkan dua setengah bulan dan pasien dipantau tiap bulan selama 
satu tahun. ${ }^{14}$ Garde melaporkan satu kasus pleomorfik adenoma pada palatum durum yang ditatalaksana dengan eksisi luas dan menggunakan flap palatal untuk membantu hemostasis dan menutup tulang yang terpapar, dilaporkan penyem-buhan luka yang cepat dengan tidak ada rekuren. ${ }^{19}$ Moubayed melakukan reseksi pleomorfik adenoma pada palatum tanpa melakukan rekonstruksi karena berharap mukosa palatum akan beregenerasi sendiri. ${ }^{11}$ Pada pasien ini telah dilakukan ekstirpasi tumor dan defek yang muncul dibiarkan sembuh sendiri. Pemantauan selama 1,5 bulan terlihat defek pada palatum sudah menutup.

Pleomorfik adenoma merupakan tumor jinak, tetapi dapat terjadi rekuren pada sebagian kecil kasus. ${ }^{9}$ Angka rekuren untuk pleomorfik adenoma adalah 2-44\%.9,14 Tranformasi ganas menjadi karsinoma ditemukan $8,5 \%{ }^{3}$ Pada dewasa muda angka rekuren setelah reseksi bedah lebih rendah. ${ }^{21}$ Rekuren dapat terjadi terutama disebabkan reseksi dan enukleasi yang

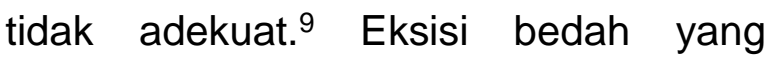
adekuat biasanya tidak ditemukan rekuren. ${ }^{13,19,22}$ Pada pasien ini belum bisa dinilai kejadian rekuren karena pemantauan baru 1,5 bulan setelah operasi.

Pleomorfik adenoma merupakan tumor jinak campuran yang mengenai kelenjar liur minor paling sering ditemukan pada palatum. Terapi pilihan untuk pleomorfik adenoma kelenjar liur adalah reseksi tumor. Kontrol secara periodik diperlukan mengingat adanya kemung-kinan tumor ini rekuren dan bertranformasi menjadi ganas.

\section{SIMPULAN}

Dilaporkan satu kasus pada seorang pasien laki-laki umur 49 tahun dengan benjolan yang tidak nyeri di palatum sejak 3 bulan sebelum masuk rumah sakit, histopatologi mengkonfirmasi pleomorfik adenoma sebagai diagnosisnya. Pada pasien ini dilakukan reseksi tumor sebagai penatalaksanaannya. Tumor jinak pada palatum sering berupa pleomorfik adenoma yang bila dilakukan reseksi tumor secara komplit memberikan prognosis yang baik.

\section{DAFTAR RUJUKAN}

1. Oh YS, Eisele DW. Salivary gland neoplasms. Dalam Bailey BJ, Johnson JT, Newlands SD, penyunting. Head \& Neck Surgery-Otolaryngology. $4^{\text {th }}$ ed. Philadelphia;Lippincott Williams \& Wilkins 2006:1530-5.

2. Sing RB, Baliarsingh RR, Satpathy $A K$, Naik CB, Nayak A, Lohar TP, Panda A. Pleomorphic adenoma of both hard and soft palate: a case report. Annals and Essences of Dentistry 2012;4(3):30-3.

3. Friedrich RE, Li L, Knop J, Giese M, Schmelzle R. Pleomorphic adenoma of the salivary glands: analysis of 94 patients. Anticancer Res 2005;25:1703-6.

4. Gurung U, Shrestha BL, Sinha BK, Baskota DK. Pleomorphic adeno-ma of salivary glands: an expe-rience at TUTH. Nepalese Journal of ENT Head \& Neck Surgery 2010;1(1):8-11.

5. Ashkavandi ZJ, Ashraf MJ, Afandak N. A clinico-pathologic study of 82 intraoral minor salivary gland tumors. Iran Red Crescent Med J 2011;13(9):674-7.

6. Wyszynska Pawelec G, Gontarz M, Zapala J, Szuta M. Minor salivary gland tumours of upper aerodi-gestive tract: a clinicopathological study. Gastroenterol Res Pract 2012;1-12.

7. Vicente OP, Marques NA, Aytes LB, Escoda CG. Minor salivary gland tumors: a 
clinicopathological study of 18 cases. Med Oral Patol Oral Cir Bucal 2008;13(9):E582-8.

8. Aggarwal A, Singh R, Sheikh S, Pallagatti S, Singla I. Pleomorphic adenoma of minor salivary gland: a case report. RSBO 2012;9(1):97-101.

9. Akpek F, Tek M, Toptaz O, Ozan F. Pleomorphic adenoma of the palate: a case report. Int J Dent Case Reports 2012;2(4):33-6.

10. Moshy J, Mwakyoma H, Owibingire S. Intraoral minor salivary glands neoplasms; the pattern and management. Professional Med J 2010;17(3):483-9.

11. Moubayed SP, AISaab F, Daniel SJ. Rapidly progressing palatal pleomorphic adenoma in an adolescent. Int J Pediatr Otorhino-laryngol 2010;5:141-3.

12. Fu H, Wung J, Wang L, Zhang $Z$, He $Y$. Pleomorphic adenoma of the salivary glands in children and adolescents. J Pediatr Surg 2012; 47:715-9.

13. Chaudhari S, Hatwal D, Ashok, Suri V. Pleomorphic adenoma of hard palate: a report of four cases. IJCRI 2013;4(2):90-4.

14. Mubeen K, Vijayalakshmi KR, Pati AR, Giraddi GB, Singh C. Benign pleomorphic adenoma of minor salivary gland of palate. J. Dent. Oral Hyg. 2011;3(6):82-8.
15. Kim KM, Lee A, Yoon SH, Kang JH, Shim SI. Carcinoma ex pleo-morphic adenoma of the palate: a case report. $\mathrm{J}$ Korean Med Sci 1997;12(1):63-6.

16. Lenka SP, Padhiary SK, Subudhi SK, Pathak $\mathrm{H}$, Sahoo S. Pleomorphic adenoma of hard palate: a case report. International Journal of Scientific and Research Publications 2013;3(1):1-3.

17. Lowry TR, Heichel DJ. Pleomorphic adenoma of the hard palate. Otolaryngol Head Neck Surg 2004;131(6):1041-55.

18. Gothwal AK, Kamath A, Pavaskar RS, Satoskar SK. Pleomorphic adenoma of the palate: a case report. Journal of Clinical and Diagnostic Research 2012;6(6): 1109-11.

19. Garde JB, Raikwar K, Kulkarni A. Pleomorphic adenoma of the hard palate. $\mathrm{J}$ Int Clin Dent Res Organ 2010;2(2):92-4.

20. Gupta M, Gupta M. Pleomorphic adenoma of the hard palate. BMJ Case Reports 2013;12.

21. Jorge J, Pires FR, Alves FA, et al. Juvenile intraoral pleomorphic adenoma: report of five cases and review of the literature. Int. J. Oral Maxillofac. Surg. 2002;31:273-5.

22. Sharma N, Singh V, Malhotra D. Pleomorphic adenoma of the hard palate $-\mathrm{a}$ case report. Indian Journal of Dental Sciences 2010;2(1):18-20. 